deal with disease, are no less excellent than the account of the normal life of the plant. In the chapters devoted to fungi such diseases as fingerand-toe, black scab, late blight, rust, and mildews are described. It is curious that no reference appears to be made to the fact that many varieties of potato are now known to resist attack by black scab-a fact of the greatest importance to allotment-holders and town gardeners. The remedies suggested for use in the case of mildews certainly do not apply to American gooseberry mildew, a disease which is so widespread and so disastrous in its consequences that it might well have received more thorough treatment. Much useful information is provided on the subject of animal pests, but gardeners with a knowledge of their ravages might look for a fuller account of eelworms, which pests are probably responsible for more damage in gardens than is any other fungus or insect. The accounts of such pests as the cabbage-root fly and the onion fly, which have been very active this year, are particularly clear. We could only wish that the measures whereby these pests are to be combated were half as good; but for more perfect measures we must look to future research, for at present they are unknown. To the reviewer at all events the absence of illustrations is no drawback; it may be, however, that the layman may find it difficult to see mentally the pests and processes without their aid. We trust not; for we hold the belief that pictures are overdone in popular books on science and in science teaching generally. F. K.

\section{PROF. DANIEL OLIVER, F.R.S.}

WITH deep regret we record the death at Kew on December $2 \mathrm{I}$, in his eighty-seventh year, of Emeritus Prof. Daniel Oliver. The eldest son of another Daniel Oliver, the deceased was born at Newcastle-upon-Tyne on February 6, I830; and was educated partly in private schools, partly at the Friends' School, Brookfield, near Wigton. Attached from an early age to botanical study and a youthful member of a local scientific society, we find him in 1847 contributing to the Phytologist a list of rare plants from different geological formations, and in $185^{\circ}$ adding a new genus to the flora of the United Kingdom. In I $85 \mathrm{I}$ he became a fellow of the Edinburgh Botanical Society, and in 1853 of the Linnean Society. His reputation as a keen and critical worker, gained in the North of England, was already such as to prompt Sir William Hooker to invite him to assist his son in the heavy task of arranging and distributing the botanical collections accumulated by the East India Company and to induce him in $185^{8}$ to become an assistant in the herbarium at Kew. On settling there Oliver instituted in 1859 a course of lectures on botany, which he continued to conduct until I874, for the benefit of the young gardeners. He proved so excellent a teacher that in $\mathrm{I} 86 \mathrm{I}$ he was appointed to the botanical chair which had been occupied by Lindley at University College, London.

NO. $246 \mathrm{I}$, VOL. 98$]$
The extent and accuracy of his botanical knowledge led to his election to the Royal Society in $186_{3}$ and to his appointment, on the retirement of $\mathrm{Mr}$. A. Black in 1864 , to the keepership of the herbarium and library at Kew. The chair at University College, now held by his distinguished son, Oliver retained until $\mathrm{r} 888$; the keepership at Kew he occupied until he retired from the public service in 1890 . After his retirement he succeeded Sir Joseph Hooker as editor, on behalf of the Bentham Trustees, of the "Icones Plantarum." This duty he fulfilled for five years, so that his connection with the institution where he worked so long, and for which he did so much, was not finally severed until $\mathrm{r} 895$.

The salient features of Oliver's contributions to botany, too numerous to be recounted here, are the accuracy of his observations, the soundness of his conclusions, and the combined fidelity and artistic skill of his illustrations. But his published works represent only a fraction of his botanical knowledge, so exact as to have earned the justifiable confidence of Sir Joseph Hooker and $\mathrm{Mr}$. Bentham while engaged in preparing their great "Genera Plantarum," so wide that Darwin, when seeking the benefit of his great knowledge of flowering plants, spoke of him to Hooker, only half in play, as the "omniscient" Oliver. This wide knowledge, the outcome of the long and patient devotion to duty of a keen and active intellect, was readily placed at the disposal of all serious students who chose to consult him. If he never sought, neither did he avoid, the outside duties that devolve on men of his capacity; he served twice on the council of the Royal, twice on that of the Linnean Society. He did strive to avoid, but could not wholly escape, honours and distinctions. In 1882 the Edinburgh Botanical Society elected him, after thirty years of ordinary membership, one of their six British honorary fellows. In 1884 the Royal Society recommended him as the recipient of a Royal medal. In $r 89 \mathrm{I}$ the University of Aberdeen conferred on him the degree of LL.D. In 1893 the Linnean Society awarded him its gold medal, and a number of friends arranged for the painting of his portrait by Mr. J. Wilson Foster for presentation to the herbarium at Kew. On his attaining his eightieth birthday in rgro old colleagues united with the existing herbarium staff in offering him an address of congratulation.

After his definite retirement from botanical pursuits in 1895 , Oliver devoted himself to his garden and to the further cultivation of that artistic gift to the possession of which his botanical illustrations testify, with such results as to warrant the belief that, had he chosen to make Art his mistress, he might well have merited in her service the eminence which his devotion to Botany deserved.

Oliver married in r86 $\mathrm{r}$ Miss Harriet Wall, of Sheffield, by whom, by his son, and by two daughters he is survived. Those whose privilege it is to have known Oliver mourn with them the loss of a true and highly gifted friend. 